\title{
Hoofstuk 11
}

\section{Die besluite van die Sinode ten opsigte van binne-kerklike \\ sake}

Die Sinode het nie net aandag gegee aan die leerkwessie nie, maar ook aan verskillende binne-kerklike sake in die tussenperiodes waar daar nie oor die leergeskil gehandel is nie. Nadat die buitelanders vertrek het, het die Sinode voortgegaan met sy werk, soos weergegee in die sogenoemde na-handelinge. Van die belangrikste sake wat behandel was, kry nou aandag.

\section{1 'n Bybelvertaling}

Die vraag na die Bybel is deel van die Protestantse Christendom. So word reeds vroeg pogings aangewend om 'n Bybel beskikbaar te stel. In 1556 het 'n Emdense drukker ' $n$ bewerking van die Zürichse Bybel beskikbaar gestel. Ook in 1556 verskyn Utenhove se letterlike, regstreekse vertaling van die Nuwe Testament. Die vertaling is in 1559 deur Dyrkinus bygewerk. Godfried van Wingen het die Ou Testamentvertaling van Luther vernederlands.

Die werk van Dyrkinus ten opsigte van die Nuwe Testament en Van Wingen se Ou Testamentbewerking word saamgevoeg in die sogenaamde Deux-Aes-Bijbel van 1561-1562. Die koddige naam is afkomstig van ' $n$ aantekening wat Luther by Nehemia 3:5 gemaak het en wat verband hou met 'n dobbelspel. Die aantekeninge of rympie wat op die voorblad verskyn het, het as volg gelees:

De armen moeten het Cruyce dragen,

de rijcken en geven niets.

Deux Aes (= die armes) en heeft niet, six cinq ( $=$ die rykes) en geeft niet,

quater-drij ( = die middestand) die helpen vrij. 
Die Deux-Aes-Bijbel was besonder geliefd by die Calviniste. Tog was die Bybel nie bevredigend nie en in 1592 het Marnix van St Aldegonde 'n opdrag gekry om die Bybel te vertaal. Met sy dood in 1598 het daar nog nie veel van gekom nie. Daarom het die Dordtse Sinode oor die saak gehandel en geoordeel dat die owerheid finansieel moet help, omdat vir daardie werk ' $n$ aantal predikante losgemaak moes word van hulle gemeentelike dienswerk. Daarby het die Sinode ook duidelike rigly. ne neergelê hoe die vertaalwerk gedoen moes word. Ten eerste moes daar so naby as moontlik aan die grondtale gebly word. Kanttekeninge moes geskrywe word by dele wat moeilik was om te vertaal. Die Apokriewe boeke moes ook vertaal word, maar die vertaling moes in ' $n$ ander lettertipe geset word om dit van die Kanonieke boeke te onderskei.

Die Bubelvertalingswerk het in 1626 begin, nadat die owerheid geld daaryoor beskikbaar gestel het. Die Ou Testament is in hoofsaak vertaal deur Bogerman en Baudartius en die Nuwe Testament is versorg deur Hommius en Walaeus. Met die hersiening en alles wat daar bygekom het, is die werk eers in 1635 voltooi. In September 1637 was die drukwerk afgehandel en kon die eerste eksemplaar aan die Staten-Generaal aangebied word. Bogerman self het kort voor die verskyning van die Bybel gesterf.

Die Bybel het as Statenbijbel bekend geword, omdat die Staten die werk gefinansier het, Oor die algemeen kan dit as ' $n$ uitnemende Calvinistiese vertaling beskou word, wat so wetenskaplik-korrek vertaal is dat selfs die Remonstrante die Bybel gebruik het. Dit het geweldig populêr geword en gebly, en na die heskikbaarstelling daarvan het dit ' $n$ vaste gewoonte in elke huisgesin geword om na ete uit die Bybel voor te lees.

$1 a^{\prime}$ usti's.

\subsection{Kategismusprediking}

Ten opsigte van die Kategismusprediking, wat op Sondagmiddae gehou moes word, het geblyk dat daar baie praktiese probleme was: die feit dat landarbeid toegelaat was op Sondae en selfs gesteun is deur die owerheid, die swak bywoning van die eredienste en die onwil van die predikante om op Sondagmiddae te preek, asook die probleem dat baie predikante twee of meer gemeentes moes bedien. Daar word egter besluit dat die Kategismusprediking gehou moet word, maar dat dit 'zeer kort' en 'zeer bevattelijk' moes wees. Nalatige predikante en gemeentelede moes onder sensuur geplaas word, terwyl die owerheid versoek is om die Sondagarbeid teen te gaan, sodat die kerkvolk geleentheid kon hê om ter kerke te gaan (sewentiende sitting). 


\subsection{Kategetiese onderrig}

Oor die kategetiese onderrig is lank gepraat en die ernstige noodsaak daarvan beklemtoon. So word in 'n drieërlei kategese onderskei, naamlik in die huis deur die ouers, in die skole deur die skoolmeesters en in die kerk deur die predikante en skoolmeesters. Aldrie moet ter hand geneem word. Ter wille van die begryplikheid, word 'n korter werkie aanbeveel in plaas van die HK, naamlik die Kort Begrip wat reeds in 1608 deur Faukelius ontwerp is en die sogenoemde ABC-Boek.

\subsection{Vasstelling van 'n kerkorde}

In Mei 1619 het die Sinode begin met sy na-handelinge en het allereers aandag gegee aan die hersiening van die Kerkorde van Den Haag van 1586. Die Sinode het besef dat hy van die owerhede afhanklik was vir die invoering van die kerkorde en het daarom taamlik vergaande toegewings aan die owerheid gemaak. So word in artikel 4 gestel dat 'n predikant nie beroep sal word 'niet zonder goede correspondentie met de Christelijke overheid ter plaatse....' Dan word in artikel 5 gestel dat die owerheid 'n deugdelike reg op teenwoordigheid op die kerklike vergaderings het en so word die hele saak van die ius patronatus gehandhaaf. Artikel 37 aanvaar die teenwoordigheid van owerheidspersone op die kerkraadsvergadering as normaal. Artikel 28 stel dat die kerklike ampsdraers die plig het om 'vlijtiglijk en oprechtelijk' die gehoorsaamheid, liefde en eerhied wat die gemeentelede vir die owerheid moet hề, te benadruk. Daarby moes die kerklike vergaderings sorg dat hulle die 'gunst der overheden' moet verwerf. Hiermee word die kerk duidelik in 'n afhanklikheidsposisie geplaas. Verder het die kerkorde die spoor van die Kerkorde van Den Haag (1586) met sorg gevolg.

Hierdie kerkorde is nie deur al die provinsiale state aanvaar nie. In Gelderland, Utrecht en Overijssel is die kerkorde aanvaar. Friesland, Groningen en Zeeland het hulle eie kerkordes behou en in Holland het ook niks verander nie.

Die Sinode het verder ' $n$ uitgebreide formulier ontwerp, wat die wyse waarop predikante instemming met die Belydenisskrifte betuig, omskryf het. Alle aankomende predikante moes dit onderteken. Daaruit blyk dat die Belydenisskrifte as norm en reël van die prediking geld. In artikel 4 van die Kerkorde word wel na die formulier verwys, maar dit word nie in die Kerkorde opgeneem nie. 


\subsection{Die teks van die Belydenisskrifte}

Die teks van die NGB en die HK is sorgvuldig nagegaan en vasgestel. Verder is besluite geneem oor die gebruik van die doopformulier en die formulier vir die bejaardedoop word goedgekeur.

'n Aantal reëling ten opsigte van kerklike feesdae word getref. Daar word gestel dat slegs Kersfees, Paasfees en Pinksterfees as kerklike feesdae sal geld en dan ook nog 'den dag van de besnijdinge en hemelvaart Christi'. Verder word bepaal dat die kerklied sal wees die berymde Psalms, die berymde tien gebooie en die Ons Vader, asook die berymde Apostolicum, die lofsange van Maria, Sagaria en Simeon. Utenhove se Gesang wat net voor die preek gesing is, $O$ God wat ons Vader is, kon behou word. Die res moes verdwyn. Datheen het dit alles in sy Psalmboek gehad, asook 'n paar liedere wat tydens en ná die maaltyd gesing kon word, asook ' $n$ aandgesang. Die het almal in die Psalmboek gebly.

Die na-handelinge is op 25 Mei 1619 afgesluit en daarmee was die Sinode se taak afgehandel.

As bykomende literatuur kan gebruik word:

Donner, J H \& Van den Hoorn, S A sj. Acta of handelingen der nationale synode...te Dordrecht ter jare 1618 en 1619. Utrecht: Den Hertog's Uitgeverij.

Doornbos, K 1967. De Synode van Dordrecht 1618-1619 getoetst aan het recht van de kerk. Amsterdam: Buijten \& Schipperheijn.

Feenstra, J G 1968. De Dordtse Leerregels. Kampen: Kok.

Graafland, C 1987. Van Calvin tot Barth: Oorsprong en ontwikkeling van de leer der verkiezing in het Gereformeerd Protestantisme. 's-Gravenhage: Uitgeverij Boeken centrum BV,

Hoenderdaal, G J 1960. Verklaring van Jacobus Aminius. Lochem: De Tijdstroom. Krüger, J G 1981. Die verhouding van uitverkiesing tot bekering met spesiale venwsing na die Dordtse Leerreëls. Pretoria: NG Kerkboekhandel.

Nauta, D (red) 1937. De Statenvertaling 1637-1937. Haarlem: De Erven F Bohn NV.

Oberman, H A 1988. De erfenis van Calvijn: Grootheid en Grenzen. Kampen: Kok. Van Itterzon, G P 1980. Johannes Bogerman. Amsterdam: Ton Bolland. 